\title{
Development and Evaluation of Compact Aquaculture System for the Application of Zero Water-Exchange Inland Aquacultures
}

\author{
Akekapot Khammi ${ }^{1}$, Maliwan Kutako ${ }^{2}$, Chayanoot Sangwichien ${ }^{3}$, and Kasidit Nootong ${ }^{1, *}$ \\ 1 Chemical Engineering Research Unit for Value Adding of Bioresources, Department of Chemical \\ Engineering, Faculty of Engineering, Chulalongkorn University, Bangkok 10330, Thailand \\ 2 Faculty of Marine Technology, Burapha University Chanthanuri Campus 22170, Thailand \\ 3 Department of Chemical Engineering, Faculty of Engineering, Prince of Songkla University, Hat Yai, \\ Songkhla 90110, Thailand \\ *E-mail: kasidit.n@chula.ac.th (Corresponding author)
}

\begin{abstract}
This study evaluated the performance of land-based compact aquaculture system integrating fibrous nitrifying biofilters and solid removal unit. The first experiment indicated that the compact aquaculture system with total biofilter length of $6.0 \mathrm{~m}$ and single solid separating was able to accommodate aquaculture weight as high as $5.0 \mathrm{~kg} / \mathrm{m}^{3}$, which corresponded to nitrogen loading rates of $8.4 \mathrm{mg} \mathrm{N} / \mathrm{L} /$ day. In the second experiment, more effective solid-liquid separation and good water quality were achieved when solid separating unit was replaced by filtration unit with Japanese mats as filtered media, and cleaning of biofilters and filtration unit was conducted in every 4 days. Next, the compact aquaculture system was employed to cultivate tilapia without water-exchange for 60 days using the described strategies. TAN and nitrite were well below acceptable limit of $1.0 \mathrm{mg} \mathrm{N} / \mathrm{L}$; suspended solids varied between 20 and $35 \mathrm{mg} \mathrm{SS} / \mathrm{L}$; and harvesting fish weights were $10.4 \mathrm{~kg} / \mathrm{m}^{3}$. Fish survival rate at $97 \%$ and average growth rate of 3.45 $\mathrm{g} /$ day were reported. Finally, solid removal remained the critical factor for successful aquacultures in the compact system even under extensive or semi-intensive aquaculture cultivation, and nitrogen mass balance indicated that nitrification-denitrification were main treatment pathways while solid removal only prolonged the activity of nitrifying biofilters.
\end{abstract}

Keywords: Aquaculture, denitrification, nitrification, RAS, solids.

ENGINEERING JOURNAL Volume 19 Issue 2

Received 15 June 2014

Accepted 5 November 2014

Published 30 April 2015

Online at http://www.engj.org/

DOI:10.4186/ej.2015.19.2.15 


\section{Introduction}

Accumulation of inorganic nitrogenous compounds, especially ammonium and nitrite, was undesirable for good aquaculture practice. These compounds at excessive levels (i.e., $>1.0 \mathrm{mg} \mathrm{N} / \mathrm{L}$ ) can cause negative health effect towards cultured animals namely inducing stress, weakening animal immune system, retarding growth or mortality [1]. Thus, farmers are forced to exchange water from cultured tanks frequently as high as 5 to 6 times daily. Discharge of aquaculture effluent containing nitrogenous compounds even at low concentrations also create various environmental concerns, namely depletion of dissolved oxygen in receiving water, toxicity towards aquatic animals and plants, eutrophication and contamination of drinking water resource [1-2]. From these reasons, employment of recirculating aquaculture systems (RAS) is perceived as a sustainable solution for aquacultures [1]. Conventionally, nitrifying biofilters and, to the lesser extent, the combination of nitrifying and denitrifying biofilters in separated compartments have been successfully employed to treat aquaculture effluent in many configurations, for example trickling filters, rotating biological contactors, fluidized sand filters, pack-bed bioreactors, and moving-bed bioreactors [38]. The mentioned biofilter systems were usually coupled with expensive and complicated solid-liquid separators to enhance the system performance. In spite of high treatment efficiencies, nitrifying and denitrifying aquaculture systems remains costly to operate due to several reasons, for example, the energy requirement for pumping water through series of unit operations, redundant aeration required in both cultured tanks and nitrifying biofilter units and requirement for high-skilled staffs to operate and maintain the systems [9-10]. In the previous work conducted in our laboratory by Sesuk et al. (2009), a compact aquaculture system was proposed by integrating fibrous nitrifying biofilters into the rearing tank [10]. The concept of such design intended to use fibrous nitrifying biofilters for the treatment of nitrogenous compounds and for the separation of suspended solids (SS) from water simultaneously as well as to reduce water circulation, with the final aims of creating a simple and affordable aquaculture system for small-scale budget-limited farmers or urban aquacultures. Early assessment of the proposed aquaculture system, which employed acclimated nitrifying biofilters (Biocord ${ }^{\mathrm{TM}}$ ) of $5.6 \mathrm{~m}$ in length revealed that the aquaculture system was able to produce good quality effluent with ammonium and nitrite concentrations less than 1.0 $\mathrm{mg} \mathrm{N} / \mathrm{L}$ and suspended solid concentrations less than $20 \mathrm{mg} \mathrm{SS} / \mathrm{L}$ [10]. However, the setback of that study includes relatively short experimental period of less than 40 days and low nitrogen loading rates ranged from 1.24 to $2.78 \mathrm{mg} \mathrm{N} / \mathrm{L} /$ day, which were equivalent to fish weight from 0.68 to $2.60 \mathrm{~kg} / \mathrm{m}^{3}$ [10]. In addition, significant solid accumulation was observed on the surface of fibrous nitrifying biofilters that led to lower ammonium degradation rates [10]. In the present study, the original design by Sesuk et al. (2009) was modified by combining with low-budget solid separating unit based on the design by Nootong et al. (2013) as means to increase the system treatment capacity at higher nitrogen waste loadings and to prolong nitrifying activity of fibrous biofilters $[8,10]$. Solid separating unit was operated based on gravitational sedimentation to separate suspended solid from water column with the maximum removal efficiencies reported around $70-72 \%$ at the optimal volumetric flow rates approximately $80 \mathrm{~L} / \mathrm{h}[8]$.

Therefore, objectives of the present study aimed to evaluate the performance of the modified compact aquaculture system, which integrated the original design of Sesuk et al. (2009) with the solid separating unit under higher nitrogen loading rates and longer cultivating period. Management and economic aspects of the compact aquaculture system were also presented.

\section{Materials and Methods}

\subsection{Biofilter Preparation}

Fibrous Biocord ${ }^{\mathrm{TM}}$ biofilters (polypropylene; $2.80 \mathrm{~m}^{2} / \mathrm{m}$ or $82.35 \mathrm{~m}^{2} / \mathrm{kg}$ biofilter) were prepared to establish nitrifying activities based on the method described in literature [10]. Biocord ${ }^{\mathrm{TM}}$ biofilters (33 pieces at $60 \mathrm{~cm}$ per piece) were submerged under water surface in acclimating tank (800 L working volume). Ammonium chloride $(7.1 \mathrm{~g})$ and $35 \%$ protein by weight shrimp diets $(28.4 \mathrm{~g})$ were added into acclimating tank to provide nitrogen source and essential minerals to mixed nitrifying cultures. Repeated additions of ammonium chloride and shrimp diets were carried out after ammonium and nitrite concentrations were lower than $1.0 \mathrm{mg} \mathrm{N} / \mathrm{L}$. Operating conditions of acclimating tank were maintained within the optimal ranges for nitrifying bacteria (i.e., $\mathrm{DO}>4.0 \mathrm{mg} / \mathrm{L}, \mathrm{pH}=7.0-8.0$, alkalinity $=100-$ $150 \mathrm{mg} \mathrm{CaCO}_{3} / \mathrm{L}$ ). 


\subsection{Compact Aquaculture System}

Schematic diagram of the compact aquaculture system with solids separating unit is illustrated in Fig. 1. Plastic tank (1,000 L working volume) was used to accommodate aquacultures, nitrifying biofilters and aeration equipment. Fibrous nitrifying BiocordTM biofilters (10 pieces at $60 \mathrm{~cm}$ per piece) as described in section 2.1 were connected to a metal frame to ensure that biofilters were able to align vertically under water. Metal frame was placed on the tank floor to submerge fibrous biofilters below the water surface. Water circulation inside the tank was accomplished by using diffusive stones and submergible pump placing on the tank floor. Solids separating unit was built from hollowed plastic PVC cylinder (inner diameter 30 $\mathrm{cm}$; height $100 \mathrm{~cm}$ ) with inside being inserted by 8-leveled horizontal plastic PVC discs (diameter $28 \mathrm{~cm}$; thickness $0.5 \mathrm{~cm}$ ), which were mounted to plastic PVC pipe (inner diameter $2.5 \mathrm{~cm}$; outer diameter $3.0 \mathrm{~cm}$; height $1.5 \mathrm{~m}$ ) with spacing between discs at $8.5 \mathrm{~cm}$. Openings for water inlet and outlet were located at 5 and $90 \mathrm{~cm}$ from the bottom of plastic cylinder, respectively. Water circulation between cultured tank and solid separating unit was maintained using pump at the upflow superficial velocity of $3.15 \times 10^{-2} \mathrm{~cm} / \mathrm{s}$ (i.e., $80 \mathrm{~L} / \mathrm{h}$ ) that resulted in solid removal efficiency approximately $70 \%$ [8]. Later in the experiment, the solid separating unit was replaced by filtration unit, which was fabricated by placing Japanese mats filter (polyester, thickness $3 \mathrm{~cm}$, diameter $28 \mathrm{~cm}$ ) in plastic basket. Water circulation at $80 \mathrm{~L} / \mathrm{h}$ from cultured tank entered filtration unit from the top and exited at the bottom before returning to cultured tank.

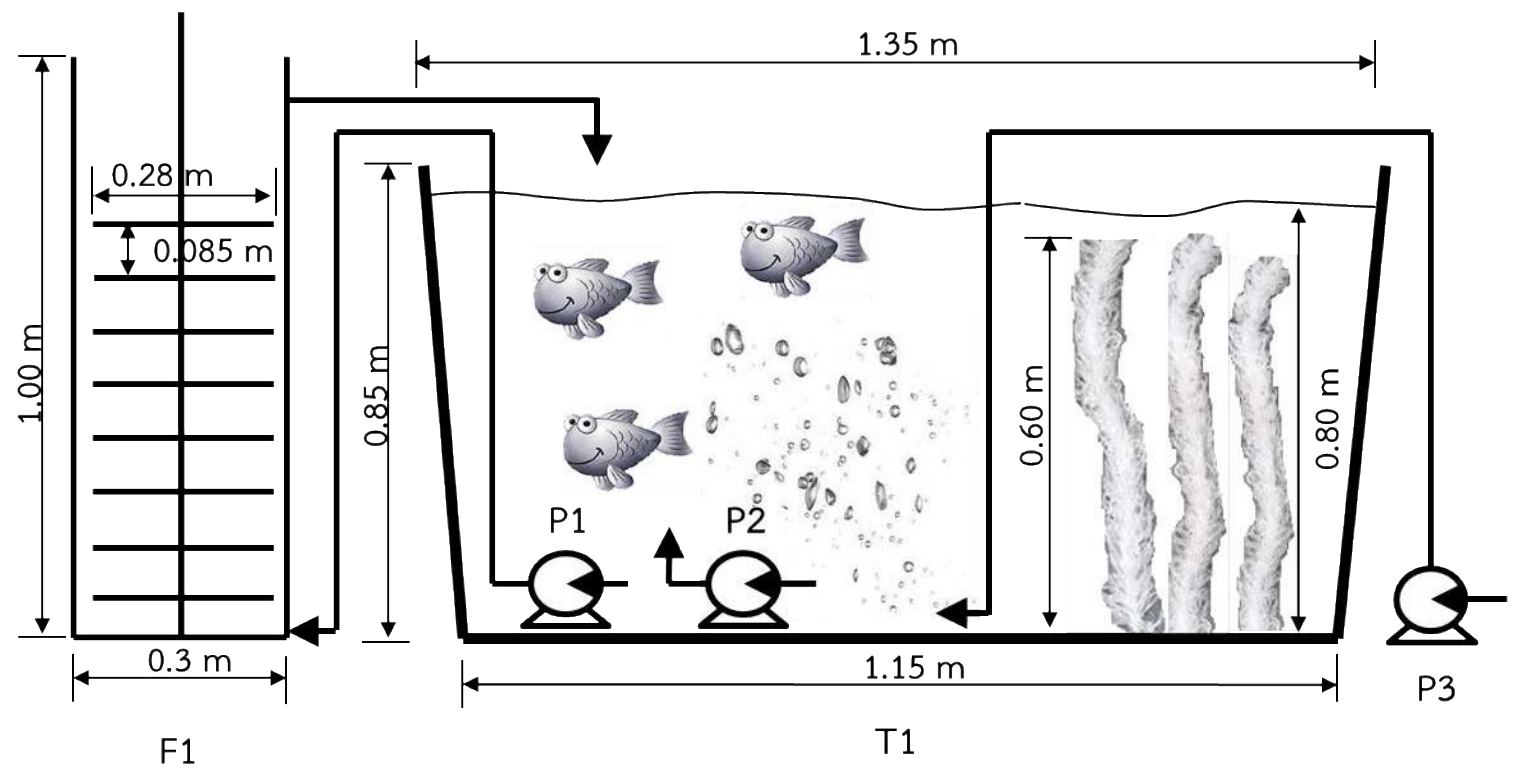

Fig. 1. Schematic diagram (not to scale) of the compact aquaculture system coupled with the solid separating unit: (T1) cultured tank, (P1) water pump between cultured tank and solid separating unit, (P2) water circulating pump in cultured tank, (P3) air pump, and (F1) solid separating unit.

\subsection{Experimental Design}

This study was divided into three main experiments. The first experiment evaluated the compact aquaculture system with solid separating unit under different nitrogen loading rates, which can be calculated using the amounts of feed given to fish daily while the amounts of feed depended on the total fish weight in cultured tanks. It was also assumed that $1 \mathrm{~g}$ of protein in aquaculture feed contained $0.16 \mathrm{~g}$ of nitrogen [11]. Nile tilapia (Oreochromis niloticus) with average weight of $118 \pm 4.6 \mathrm{~g} /$ fish were stocked in cultured tanks to attain initial fish weight of approximately $3.0 \mathrm{~kg} / \mathrm{m}^{3}$, which were equivalent to the nitrogen loading rates of $5.1 \mathrm{mg} \mathrm{N} / \mathrm{L} /$ day. Feeding was performed twice daily using $35 \%$ protein commercial feed pellets at $3 \%$ of the total fish weight in the tank per day. Relatively constant fish weights (i.e., nitrogen loading rates) in the aquaculture system were maintained by removing fish from cultured tank periodically. During the assessment, the solids separating unit was operated continuously for 14 days and then disconnected from cultured tanks for the remainder of the experiment (i.e., day $15-21$ ). Conditions in cultured tank 
throughout the experiment were maintained as follows: $\mathrm{pH}=7-8, \mathrm{DO}>4.0 \mathrm{mg} / \mathrm{L}$ and alkalinity $=100-$ $150 \mathrm{mg} \mathrm{CaCO} / \mathrm{L}$. Daily water samples were obtained from cultured tank and immediately analyzed for the concentrations of ammonium, nitrite, nitrate and suspended solid according to the Standard Methods [12]. The same procedure was repeated for higher tilapia weights of $5,7,9$ and $11 \mathrm{~kg} / \mathrm{m}^{3}$.

Results of the first experiment revealed the excessive solid accumulation on biofilter surface especially at high fish weights. Therefore, in the second experiment, suitable procedure for system management specifically the method of biofilter cleaning and the frequency of cleaning were explored based on the optimal fish weight obtained in the first experiment. Tilapia cultivation in the compact aquaculture system coupled with the solid separating unit was conducted for 60 days with fish weights in cultured tank maintained relatively constant at $7 \mathrm{~kg} / \mathrm{m}^{3}$. From Day 1 to 10 , the compact aquaculture system and solid separating unit were operated as normal using the water flow rates of $80 \mathrm{~L} / \mathrm{h}$. The next period, which extended from Day 11 to 20 , the solid separating unit was still operated as normal at $80 \mathrm{~L} / \mathrm{h}$ but fibrous nitrifying biofilters were taken out of cultured tank daily and cleaned by light scratching and rinsing with clean water using low pressure water hose. Cleaning process required approximately 20 to 30 minutes. From Day 21 to 45, solid separating unit was replaced by filtration unit with Japanese mats acted as filtered media. During this period, filtered media and nitrifying biofilters were cleaned by scratching and rinsing with water in every 4 days. For the remainder of the experiment (i.e., Day 46 to 60), the same procedure was carried out but the frequency of cleaning was reduced by half to every 2 days. Tilapia feeding was still performed twice daily using 35\% protein commercial pellets at 3\% of the total fish weight per day. Condition in cultured tanks was maintained under suitable range for nitrification and tilapia growth (i.e., $\mathrm{pH}$ $=7-8, \mathrm{DO}>4.0 \mathrm{mg} / \mathrm{L}$ and alkalinity $=100-150 \mathrm{mg} \mathrm{CaCO} / \mathrm{L}$ ) for the entire cultivation. Daily water samples from cultured tanks were obtained and analyzed for the concentrations of ammonium, nitrite, nitrate and suspended solids according to the Standard Methods [12].

The final experiment operated the compact aquaculture system using the recommended management strategies obtained from the second experiment to grow tilapia without water exchange for 60 days. Nile tilapia with average weight of $81.4 \pm 5.2 \mathrm{~g}$ were stocked in cultured tanks to attain initial fish weight of 3.0 $\mathrm{kg} / \mathrm{m}^{3}$. Tilapia were fed twice daily with $35 \%$ protein commercial feed pellets at $3 \%$ of the total fish weight per day. Approximately $30 \%$ of tilapia population was sampled and measured for its weight and length in every 3 weeks. Constant aeration by diffusive stones and $\mathrm{NaHCO}_{3}$ addition were carried out to maintain proper conditions for nitrifying bacteria and tilapia (i.e., $\mathrm{DO}>4.0 \mathrm{mg} / \mathrm{L}, \mathrm{pH}=7-8$ and alkalinity $=100-$ $150 \mathrm{mg} / \mathrm{L} \mathrm{CaCO}_{3}$ ). The compact aquaculture system and filtration unit were operated using the same flow rates at $80 \mathrm{~L} / \mathrm{h}$. Cultivating tanks were located outdoors under shade and covered with black plastic sheet $(0.5 \mathrm{~cm}$ thick) to prevent rainwater and sunlight. Water samples from cultured tank were obtained daily and analyzed for the concentrations of ammonium, nitrite, nitrate and suspended solid according to the Standard Methods [12].

\subsection{Analytical Methods}

Prior to water sampling, water in cultured tank was agitated manually using a long wooden stick to suspend solids settled on the tank floor. Water samples approximately $1 \mathrm{~L}$ from cultured tank were obtained daily in the afternoon and subsequently settled in an Imhoff cone. Settled solids were dried at least for 24 hours in an temperature-controlled oven at $105{ }^{\circ} \mathrm{C}$ and analyzed for weight percent of carbon, hydrogen and nitrogen using a CHN analyzer (Perkin Elmer PE2004) based on Pregl-Dumas method. Approximately 25 $\mathrm{mL}$ of clarified water sample in an Imhoff cone was filtered using Whatmann filter (pore size $=0.5 \mu \mathrm{m}$ ) and analyzed for total ammonia nitrogen (TAN) using APHA method 4500- $\mathrm{NH}_{3}-\mathrm{D}$, for nitrite $\left(\mathrm{NO}_{2}-\mathrm{N}\right.$ ) using APHA method $4500-\mathrm{NO}_{2}-\mathrm{B}$, for nitrate $\left(\mathrm{NO}_{3}-\mathrm{N}\right)$ using APHA method $4500-\mathrm{NO}_{3}-\mathrm{B}$, and for total suspended solids using APHA method 2540-Solids-D. Remaining clarified water in an Imhoff cone was returned to cultured tank. During the second experiment, the statistical analysis (t-test: paired two-sample for means) for TAN and suspended solid concentrations between the data from Day $31-45$ and those from Day 46 - 60 was performed using Microsoft Excel 2007. 


\section{Results and Discussion}

\subsection{Preliminary Evaluation}

Ranges of physical parameters namely temperature $\left(26.0-29.0^{\circ} \mathrm{C}\right), \mathrm{pH}(6.8-8.1)$, dissolved oxygen (DO) concentration $(6.8-7.1 \mathrm{mg} / \mathrm{L})$ and alkalinity $(90-160 \mathrm{mg} \mathrm{CaCO} / \mathrm{L})$ were within the practical ranges for tilapia cultivation [6]. The nitrogen loading rate, selected as the main experimental variable, can be calculated by using the amounts of feed given to tilapia on the daily basis. This resulted in the nitrogen loading rates varying from 5.1 to $18.5 \mathrm{mg} \mathrm{N} / \mathrm{L} /$ day. The specified nitrogen loading rates were equivalent to increasing fish weights in cultured tank from 3 to $11 \mathrm{~kg} / \mathrm{m}^{3}$. Clearly, the range of nitrogen loading rates applied in this experiment was greater than the maximum value of $2.78 \mathrm{mg} \mathrm{N} / \mathrm{L} /$ day reported during initial evaluation by Sesuk et al. (2009) [10]. At a given nitrogen loading rate, tilapia cultivation was carried out in the compact aquaculture system in parallel to solid separating unit operation for 14 days, followed by shutting the solid separating unit for the remainder of the experiment (i.e., Day 15 - 21). According to Fig. 2 (a), increasing the nitrogen loading rates from 5.1 to $18.5 \mathrm{mg} \mathrm{N} / \mathrm{L} /$ day led to the rapid rise of suspended solid concentrations regardless of whether solid removal was conducted. The increase in suspended solid concentrations in cultured tank was expected because solid formation in aquaculture tank was the direct consequence of feeding that led to animal excretions, unconsumed feed residues and formation of microbial biomass or bioflocs [1]. Operation of solid separating unit also influenced the levels of suspended solids in cultured tank. With solid separating unit running continuously, suspended solid concentrations in cultured tank were low (i.e., $20-40 \mathrm{mg} \mathrm{SS} / \mathrm{L}$ ) and relatively constant given that the nitrogen loading rates from feeding did not exceed $8.4 \mathrm{mg} \mathrm{N} / \mathrm{L} /$ day. Beyond this point, suspended solid concentrations increased gradually at first and began to rise more quickly to $184 \mathrm{mg} \mathrm{SS} / \mathrm{L}$. Without operating the solid separating unit, suspended solid concentrations were observed to increase very rapidly from 65 to $708 \mathrm{mg} \mathrm{SS} / \mathrm{L}$. Excessive accumulation of solids on biofilter surface was also observed during non-operational period of solid separating unit. The presence of solids on biofilters was undesirable because their biodegradation yielded dissolved organic carbon that could stimulate the growth of heterotrophic bacteria, thereby leading to lower nitrifying treatment rates of biofilters [14-15].

Nitrogen loading rate and mode of operation of solid separating unit remained key factors that influenced the ability of the compact aquaculture system to control TAN concentrations as shown in Fig. 2(b). With a single solid separating unit in operation, TAN concentrations in cultured tank could be effectively maintained below the practical limit of $1.0 \mathrm{mg} \mathrm{N} / \mathrm{L}$ given that the nitrogen loading rates from feeding were less than $8.4 \mathrm{mg} \mathrm{N} / \mathrm{L} /$ day. Further increase of nitrogen loading rates to the range between 15.1 and $18.5 \mathrm{mg} \mathrm{N} / \mathrm{L} /$ day led to a significant increase in TAN concentrations in cultured tank to approximately $20 \mathrm{mg} \mathrm{N} / \mathrm{L}$. Such extremely high TAN concentrations were dangerous towards aquatic animals and required immediate water exchange to lower the concentrations [13]. Without solid removal, the compact aquaculture system was clearly ineffective in maintaining acceptable TAN concentrations, which were measured in the range from 6.4 to $22.3 \mathrm{mg} \mathrm{N} / \mathrm{L}$ for all nitrogen loading rates applied except at $5.1 \mathrm{mg} \mathrm{N} / \mathrm{L} /$ day (i.e., $3 \mathrm{~kg} / \mathrm{m}^{3}$ of fish weight). Nitrite concentrations in cultured tank were negligible and fluctuated in the narrow range between 0.1 and $0.5 \mathrm{mg} \mathrm{N} / \mathrm{L}$ regardless of solid removal being conducted as displayed in Fig. 2(c). Comparable nitrate profiles between both operating conditions were also noticeable as illustrated in Fig. 2(d). Nitrate concentrations increased to the maximum (i.e., $25-28 \mathrm{mg}$ N/L) when the nitrogen loading rates were maintained at $11.8 \mathrm{mg} \mathrm{N} / \mathrm{L} /$ day followed by a decreasing trend after the nitrogen loading rates from tilapia feeding continued to rise. Such concentration profiles of nitrite and nitrate might suggest the establishment of heterotrophic denitrification in the compact aquaculture system. Occurrence of heterotrophic denitrification was possible because excessive solid accumulation on biofilters could create anaerobic zone required by denitrifying bacteria while organic carbon source was available from biological degradation of accumulated solids. Occurrence of simultaneous nitrification and denitrification was also reported elsewhere in biofilter systems treating aquaculture effluent as well as domestic and industrial nitrogenous wastewater [16-19]. 

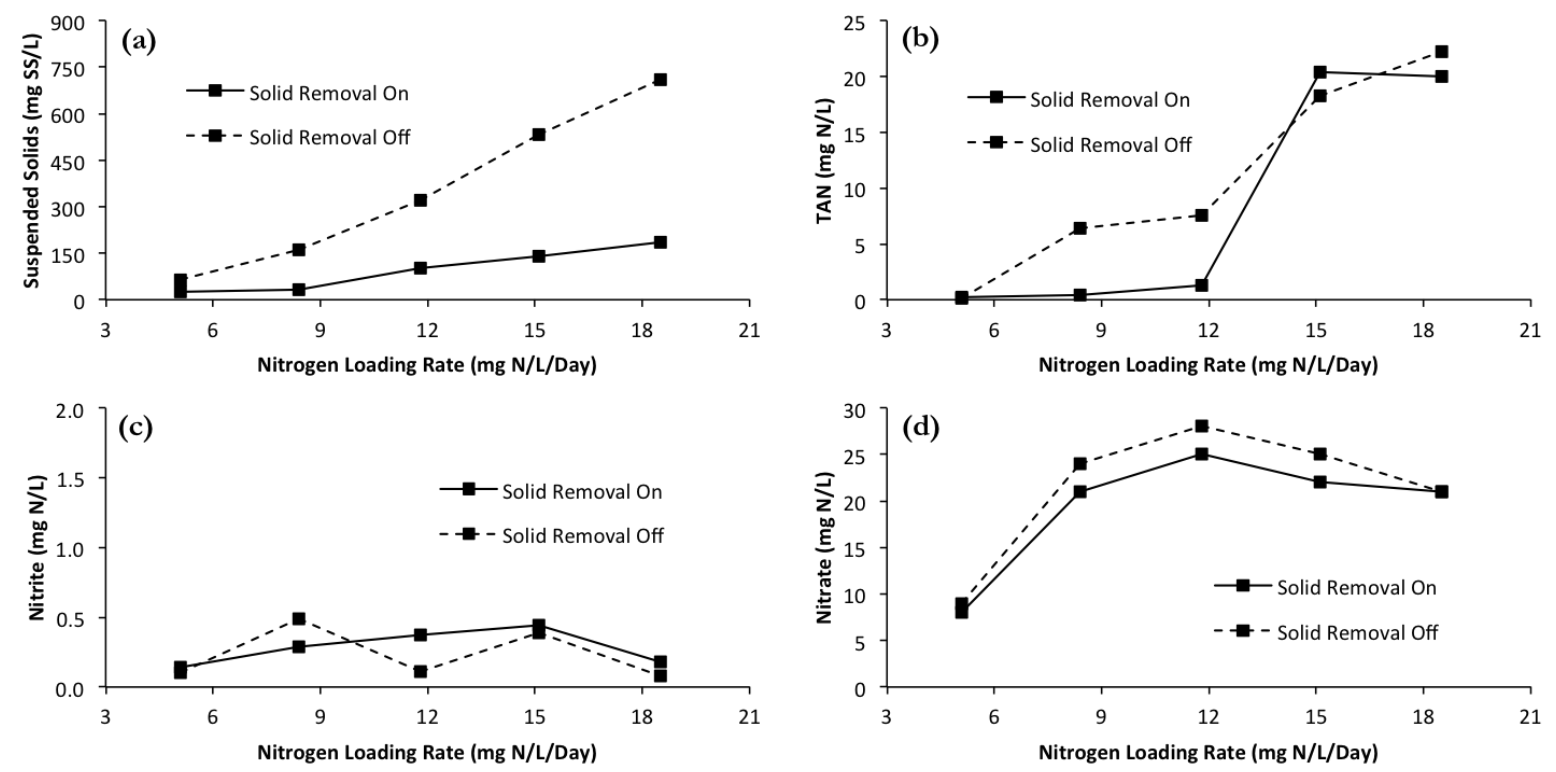

Fig. 2. Concentrations of suspended solids, TAN, nitrite and nitrate in cultured tank at different nitrogen loading rates.

\subsection{System Management Strategy}

Based on the results of the first experiment, the performance of compact aquaculture system depended primarily on the operation of solid separating unit as well as the presence of active nitrifying biofilters. This led to the conclusion that the compact aquaculture system should not be employed to accommodate aquacultures above $5.0 \mathrm{~kg} / \mathrm{m}^{3}$ (i.e., $8.4 \mathrm{mg} \mathrm{N} / \mathrm{L} /$ day). In order to improve on that result, various management strategies, specifically the method of solid-liquid separation and the frequency of biofilter cleaning, were studied during the closed-water tilapia cultivation at relatively constant weight of $7.0 \mathrm{~kg} / \mathrm{m}^{3}$. Results of water analysis under different management strategies are illustrated in Fig. 3. The compact aquaculture system given the total biofilter length of $6.0 \mathrm{~m}$ and a single solid separating unit were operated normally for the first 20 days. During this period, suspended solid concentrations in cultured tank increased rapidly, exceeding the legal discharged limit of $70 \mathrm{mg} \mathrm{SS} / \mathrm{L}$ on Day 4 and finally reaching $352 \mathrm{mg}$ SS/L on Day 20. TAN and nitrite concentrations were relatively constant and remained low (i.e. $<0.6 \mathrm{mg}$ $\mathrm{N} / \mathrm{L}$ ) during the first two weeks but showed the increasing profiles after Day 16. TAN and nitrite concentrations were measured at 1.88 and $0.94 \mathrm{mg} \mathrm{N} / \mathrm{L}$ on Day 20, respectively. The results obtained agreed with the earlier outcomes that did not recommended using the compact aquaculture system coupled with one solid separating unit to grow aquacultures when animal weights were greater than $5.0 \mathrm{~kg} / \mathrm{m}^{3}$.

In order to improve the system effectiveness, fibrous nitrifying biofilters were taken out of cultured tank to remove accumulated solids on biofilter surface by rinsing with clean water and scratching by hands. This operation was performed daily from Day 21 to 30 while the solid separating unit was still operated as normal. The combination of daily biofilter cleaning and operating solid separating unit was unable to improve the system performance as can be seen by the continuous increase of suspended solid concentrations to as high as $457 \mathrm{mg} \mathrm{SS} / \mathrm{L}$ measured on Day 30 as well as the detection of TAN at high levels (i.e., $1.78 \pm 0.10 \mathrm{mg} \mathrm{N} / \mathrm{L}$ ). Heterotrophic denitrification might be occurring in the compact aquaculture system during this period as well since the sharp decline of nitrate from 33 to $9 \mathrm{mg} \mathrm{N} / \mathrm{L}$ was observed.

Apparently, the method for solid removal should be adjusted. Thus, in the next period (i.e., Day 31 45), solid-liquid separation by solid separating unit was replaced by filtration unit with Japanese mats as filtered media. Japanese mats media were common in ornamented fish rearing. Moreover, cleaning of filtration unit and nitrifying biofilters were carried out in every 4 days by light scratching and rinsing with clean water. Under the new management strategy, turbidity of water in cultured tank improved considerably as indicated by the clear observation of tilapia swimming in cultured tank. Results of water analysis, as shown in Fig. 3, confirmed that by displaying the significant decrease of suspended solid 
concentrations in cultured tank in comparison to those reported during the last period. Suspended solid concentrations were measured at $44 \pm 5 \mathrm{mg} \mathrm{SS} / \mathrm{L}$ while inorganic nitrogen concentrations varied within the narrow ranges from 0.41 to $0.89 \mathrm{mg} \mathrm{N} / \mathrm{L}$ for TAN and from 0.12 to $0.41 \mathrm{mg} \mathrm{N} / \mathrm{L}$ for nitrite. Comparable profiles of suspended solids and inorganic nitrogen compounds were observed after the periodic biofilter cleaning were reduced by half to once in every 2 days. Under the latest management strategy, TAN and nitrite concentrations were insignificantly different $(p<0.05)$ to those of earlier period (i.e., Day 31 to 45) while suspended solid concentrations decreased slightly to about $27 \pm 6 \mathrm{mg} \mathrm{SS} / \mathrm{L}$. For nitrate, its concentrations were noticed to increase from 18 to $40 \mathrm{mg} \mathrm{N} / \mathrm{L}$ during the filtered period, which extended from Day 31 to 60. Increasing nitrate and insignificant TAN and nitrite levels were clear indications that nitrification was fully established and acted to control inorganic nitrogen concentrations in cultured tank within acceptable range (i.e., $<1.0 \mathrm{mg} \mathrm{N} / \mathrm{L}$ ).
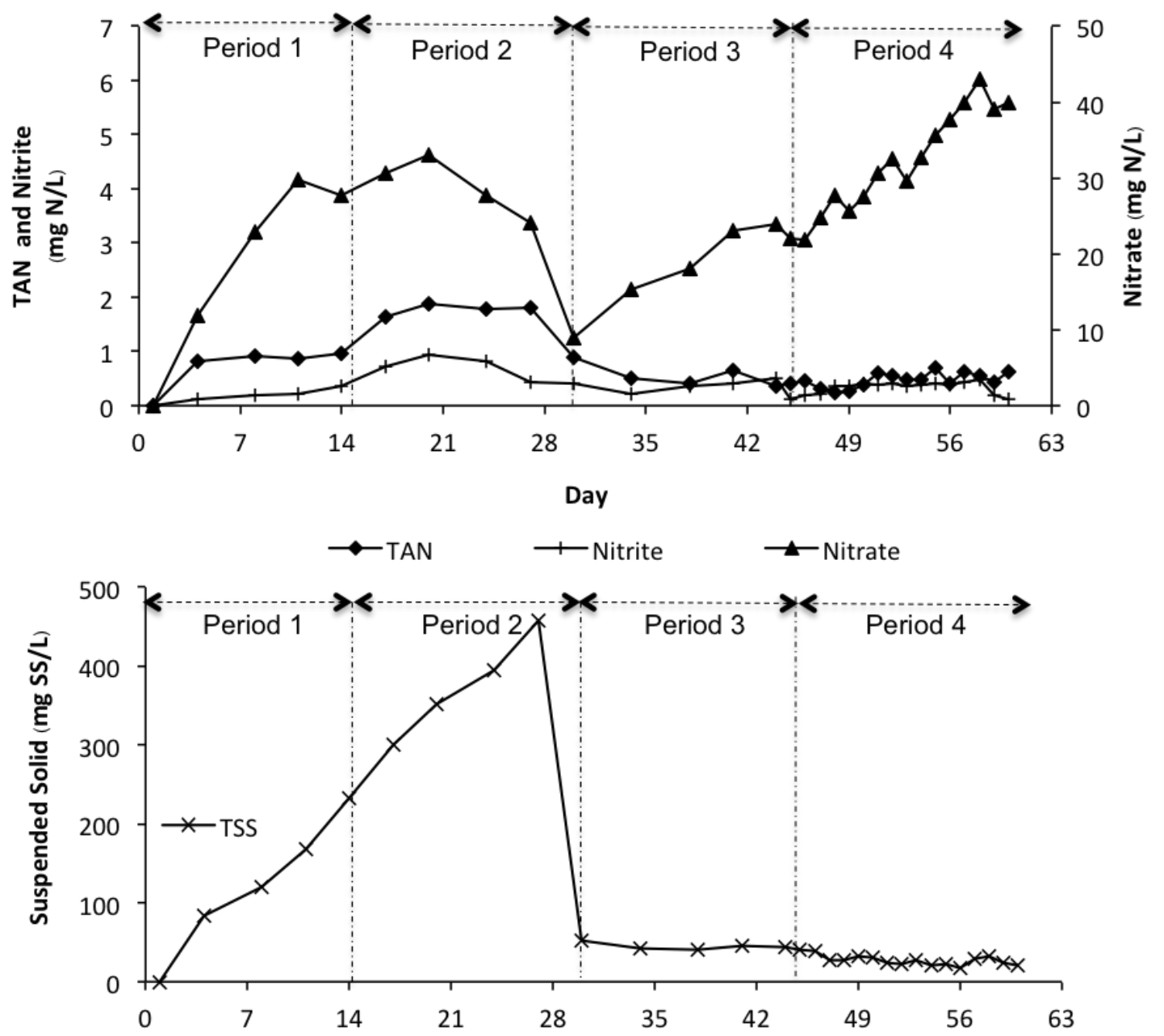

Day

Fig. 3. Profiles of suspended solids and inorganic nitrogen compounds in the cultured tank during the experiment to determine suitable management strategy: Period 1 (operating the solid separating unit only), Period 2 (operating the solid separating unit and daily biofilter cleaning), Period 3 (operating filtration unit and biofilter cleaning in every 4 days), and Period 4 (operating filtration unit and biofilter cleaning in every 2 days).

\subsection{Tilapia Cultivation in Compact Aquaculture System}

Based on the results of section 3.2, the compact aquaculture system was effective in maintaining inorganic nitrogen and solid concentrations when filtration and periodical biofilter cleaning were used in every 4 days. 
Therefore, the compact aquaculture system was operated in this experiment with the described strategy to grow tilapia without water-exchange for 60 days. The initial fish weights in cultured tank were approximately $3.0 \mathrm{~kg} / \mathrm{m}^{3}$, which corresponded to the nitrogen loading rates of $5.1 \mathrm{mg} \mathrm{N} / \mathrm{L} /$ day. Ranges of water physical parameters in cultured tank were within the acceptable ranges for tilapia cultivation (Table 1). Profiles for those parameters including temperature, $\mathrm{pH}$ and $\mathrm{DO}$ were relatively constant throughout the cultivation except for alkalinity, which required lime addition on a weekly basis to prevent a decreasing trend. Table 2 shows tilapia growth data during the cultivation. High tilapia survival rate was reported at $97 \%$. Fish death occurred on Day 10 when the compact aquaculture system were operated without solid removal that accompanied by excessive TAN and nitrite concentrations in water. The daily growth rates of tilapia (i.e., $3.45 \mathrm{~g} /$ day) in this study were higher than those of the previous studies, which employed nitrifying biofilters or other means (e.g., biofloc system) to maintain good water quality that reported the growth rates ranged from 1.03 to $3.6 \mathrm{~g} /$ day $[7,24-27]$. Higher growth rates obtained in the current study could be related to good water quality for most part of the cultivation as well as the utilization of high protein diets.

Table 1. Physical parameters of water in cultured tank during the closed-water tilapia cultivation in the compact aquaculture system.

\begin{tabular}{lccc}
\hline Parameters & Range & Average & Recommended Range $[6]$ \\
\hline $\mathrm{DO}(\mathrm{mg} / \mathrm{L})$ & $5.5-6.6$ & $5.9 \pm 0.41$ & $>4.0$ \\
Temperature $\left({ }^{\circ} \mathrm{C}\right)$ & $29.7-30.9$ & $30.2 \pm 0.5$ & $20-35$ \\
$\mathrm{pH}$ & $7.1-7.6$ & $7.3 \pm 0.11$ & $6.5-8.5$ \\
Alkalinity $\left(\mathrm{mg} \mathrm{CaCO}_{3} / \mathrm{L}\right)$ & $90-130$ & $106 \pm 12$ & $50-300$ \\
\hline
\end{tabular}

Table 2. Growth performance of tilapia during the zero-water exchange cultivation in the compact aquaculture system for 60 days.

\begin{tabular}{lr}
\hline Parameters & Average \\
\hline Initial tilapia weight $(\mathrm{g} / \mathrm{fish})$ & $81.4 \pm 5.2$ \\
Final tilapia weight $(\mathrm{g} / \mathrm{fish})$ & $187.6 \pm 40.7$ \\
Initial total tilapia weight $\left(\mathrm{kg} / \mathrm{m}^{3}\right)$ & 3.0 \\
Final total tilapia weight $\left(\mathrm{kg} / \mathrm{m}^{3}\right)$ & 10.4 \\
Survival rate $(\%)$ & 97 \\
Growth rate $(\mathrm{g} /$ day $)$ & \\
$\quad$ Entire cultivation $(60$ days $)$ & 3.45 \\
$\quad$ Day 1 - 14 & 1.31 \\
$\quad$ Day $14-60$ & 4.08 \\
\hline
\end{tabular}

Profiles of suspended solid and inorganic nitrogen concentrations during the 60-day cultivation are demonstrated in Fig. 4. During the initial period from Day 1 to 14, the compact aquaculture system was operated without solid removal while the nitrogen loading rates from daily tilapia feeding increased from 5.1 to $6.66 \mathrm{mg} \mathrm{N} / \mathrm{L} /$ day. As expected, suspended solid and inorganic nitrogen concentrations increased from 5 to $69 \mathrm{mg} \mathrm{SS} / \mathrm{L}$ and from 0.1 to $2.6 \mathrm{mg} \mathrm{N} / \mathrm{L}$, respectively. The rapid increase of those parameters to harmful levels confirmed the importance of providing sufficient solid-liquid separation as well as possessing active nitrifying biofilters to maintain good water quality in closed-aquaculture system even at relatively low fish weights in cultured tank (i.e., $<5.0 \mathrm{~kg} / \mathrm{m}^{3}$ ). For the remaining of the experiment (i.e., Day $15-60$ ), the compact aquaculture system was maintained according to the latest management strategy, specifically performing continuous filtration and biofilter cleaning in every 4 days. Nitrogen loading rates applied to the compact aquaculture system during this period increased from 6.66 to $17.4 \mathrm{mg} \mathrm{N} / \mathrm{L} /$ day. Suspended solid concentrations varied between 20 and $35 \mathrm{mg} \mathrm{SS} / \mathrm{L}$ for the remainder of the cultivation while TAN and nitrite concentrations could be kept well below the practical limit (i.e., $<1.0 \mathrm{mg} \mathrm{N} / \mathrm{L}$ ) with the average values determined at $0.41 \pm 0.19$ and $0.57 \pm 0.17 \mathrm{mg} \mathrm{N} / \mathrm{L}$ for TAN and nitrite, respectively. Clearly, the compact aquaculture system, which integrated nitrifying Biocord ${ }^{\mathrm{TM}}$ biofilters $(6.0 \mathrm{~m}$ in length) and filtration 
unit, was effective in maintaining water quality for good aquaculture practice although the nitrogen loading rates as high as $17.4 \mathrm{mg} \mathrm{N} / \mathrm{L} /$ day were reached. It should also be pointed out that the maximum nitrogen loading rate applied in this cultivation were approximately 2 times higher than the recommended values (i.e., $8.4 \mathrm{mg} \mathrm{N} / \mathrm{L} /$ day) described in section 3.1 when the system employed one solid separating unit.

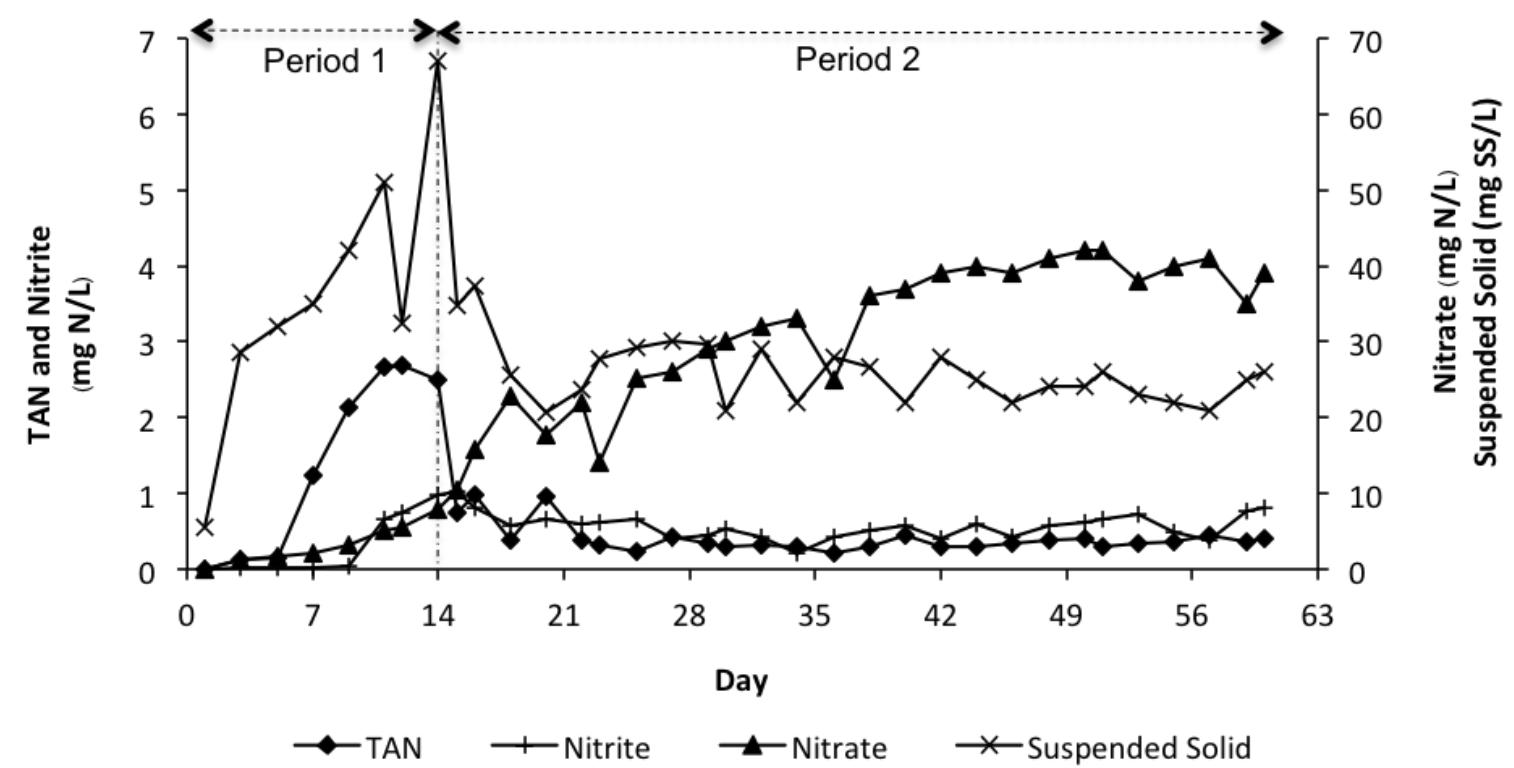

Fig. 4. Profiles of suspended solids and inorganic nitrogen compounds in cultured tank during the 60days zero-water exchange tilapia growout in the compact aquaculture system; Period 1 (no solid removal), and Period 2 (operating filtration unit and cleaning nitrifying biofilter and filtration unit in every 4 days).

Results of nitrogen mass balance calculation are displayed in Table 3. The majority of nitrogen input (i.e., $99.6 \%$ ) to the aquaculture system was primarily from fish feeding. The nitrogen distributions at the end of the cultivation were in various forms of dissolved inorganic nitrogen compounds (i.e., TAN, nitrite and nitrate), biological solids and weight gains in tilapia. Nitrogen in tilapia was assumed at $2.6 \%$ of tilapia wet weight [20]. Percentages of nitrogen in biological solids were from CHN analysis, which revealed the nitrogen contents of $3.5 \%$ on dried weight basis. The amounts of biological solids were the sum of suspended solids in water and those removed from cultured tank using filtration unit and in rinsing water. The percentages of nitrogen retention in fish (i.e., 39.3\%) reported in this study were comparable to those of other works, which showed the nitrogen retention ranged from 25 to $40 \%$ [7, 10, 21, 22]. Solid removal by filtration unit was apparently not the primary means for inorganic nitrogen control in the compact aquaculture system because it accounted for only $9.61 \%$ of the total nitrogen input. However, the presence of filtration unit remained critical for the effectiveness of nitrifying biofilters since it kept suspended solids at low levels in water, thereby preventing favorable condition required by heterotrophic bacteria. The obtained results also indicated the necessity of providing sufficient solid-liquid separation in both extensive and semi-intensive aquaculture cultivations, whereas the previous works focused mainly on solid-liquid separation in intensive or super-intensive cultivation where the fish weights were greater than $40 \mathrm{~kg} / \mathrm{m}^{3}[7]$. In addition, large amounts (i.e., 42.67\%) of nitrogen input were unaccounted for and could be assumed in the form of nitrogen gas, which is the end of product of denitrification. Nitrogen loss via ammonia volatilization was not expected to be substantial in this study because TAN concentrations were low and the $\mathrm{pH}$ values were suitable for ammonia to be in soluble form (i.e., $\mathrm{NH}_{4}^{+}$). The magnitude of nitrogen loss in this cultivation was similar to Nootong et al. (2013), who reported the nitrogen loss as high as $49.8 \%$ during the zero-water exchange tilapia cultivation in a nitrifying-denitrifying biofilter system [8]. Nitrogen loss as high as $55 \%$ was also reported in brackish ponds with very limited water discharge [23]. Occurrence of heterotrophic denitrification was possible in this experiment due to the effectiveness of fibrous Biocord $^{\mathrm{TM}}$ biofilters in retaining solids on the surface [10], thereby creating anaerobic environment that facilitated the onset of denitrification while the trapped solids provided organic carbon source for denitrifying bacteria. Filtration unit was another likely source of heterotrophic denitrification due to high 
solid accumulation on filtered media. The occurrence of simultaneous nitrification and heterotrophic denitrification in the compact aquaculture system was undesirable at the moment although it could lead to the complete nitrogen transformation to harmless compound (i.e., $\mathrm{N}_{2}$ ) and possible reduction in operational cost and equipment sizing [16, 18-19]. The reasons for that were related to the difficulty in predicting the onset of denitrification using the farmer existing equipment as well as higher cost of investment for sophisticated controlled equipment.

Table 3. Nitrogen mass balance calculation displaying the distribution of nitrogen in the compact aquaculture system.

\begin{tabular}{lr}
\hline Parameters & Values \\
\hline Nitrogen input & \\
Feed pellets $(\mathrm{g} \mathrm{N})$ & $485(99.6 \%)$ \\
Seeding water $(\mathrm{g} \mathrm{N})$ & $2.15(0.4 \%)$ \\
Total input $(\mathrm{g} \mathrm{N})$ & $487.15(100 \%)$ \\
Nitrogen on Day 60 & \\
Tilapia weight gain $(\mathrm{g} N)$ & $191.6(39.3 \%)$ \\
Suspended solids in water $(\mathrm{g} \mathrm{N})$ & $0.875(0.18 \%)$ \\
Removed solids $(\mathrm{g} N)$ & $46.8(9.61 \%)$ \\
TAN (g N) & $0.37(0.08 \%)$ \\
Nitrite $(\mathrm{g} N)$ & $0.76(0.16 \%)$ \\
Nitrate $(\mathrm{g} \mathrm{N})$ & $39(8 \%)$ \\
Unaccounted nitrogen $(\mathrm{g} \mathrm{N})$ & $207.8(42.67 \%)$ \\
\hline
\end{tabular}

The final aquaculture weights in this cultivation (i.e., $10.4 \mathrm{~kg} / \mathrm{m}^{3}$ ) were significantly higher than the harvesting weights of inland aquaculture in Thailand that reported the values ranged from 1.0 to $2.0 \mathrm{~kg} / \mathrm{m}^{3}$ [28]. Final fish weights in this study remained lower than those of the cage cultures (i.e., $30-40 \mathrm{~kg} / \mathrm{m}^{3}$ ), which were known to be highly susceptible to the water quality variation from upstream and were environmental unfriendly due to the direct disposal of nitrogenous waste into receiving water. With better system management namely appropriate solid removal method, optimal frequency for biofilter cleaning, improved fish strain, and improvement of feed quality as well as feeding methods, the final fish yields were expected to be significantly higher than the current ones and should be able to match with those intensive recirculating aquaculture systems equipped with efficient solid-liquid separators and other complicated equipment (e.g., skimmer, infection device, denitrifying biofilter and etc) that reported the fish weights in the range from 20 to $100 \mathrm{~kg} / \mathrm{m}^{3}[6,26]$. In term of operation, the compact aquaculture system was relatively easy to built and operate. Fibrous nitrifying biofilters (Biocord ${ }^{\mathrm{TM}}$ ) came in the form of rope, which was easy to be adapted under different situations. Based on the authors experience, removal of attached solids from biofilter surface and from filtration unit was easy and could be accomplished by rinsing or spraying with clean water using low-pressure water hose and by light scratching by hands. The entire cleaning process required approximately 20 to 30 minutes and was not energy intensive as opposed to more complicated systems such as microbeads biofilters and fluidized-bed sand filters, which required intensive energy during backwashing [29]. Despite the compact aquaculture system possessing many advantages, the revenue generated from selling tilapia (i.e., $468 \mathrm{Baht}$ ) in this experiment was substantially less than the sum of total construction and operational costs as demonstrated in Table 4. Construction cost estimated at 7,590 Baht accounted for as high as $95 \%$ of the total cost while operational cost was only 434 Baht for the 60-days cultivation. Plastic rearing tank was the most expensive item, which incurred the expense of 4,500 Baht. However, the mentioned equipments including biofilters were durable and could be used for many years, and with appropriate adjustment to the system, for example building fish tank from cement or using existing tanks or using local materials as biofilters, the construction and equipment expense should be further reduced. In order to improve the economical feasibility as well as to increase the attractiveness to farmers, the compact aquaculture system might be employed to cultivate high-valued aquatic species such as sea bass, grouper or shrimp broodstock. 
Table 4. Construction cost of the compact aquaculture system and the operational cost incurred during the 60-day tilapia growout without water exchange in the compact aquaculture system.

\begin{tabular}{lccc}
\hline Details & Cost (Baht) & Cost (US dollars) & 1 \\
\hline Construction Cost & & & \\
$\quad$ Plastic tank (1,000 L) & 4,500 & 139 & 42 \\
$\quad$ Biocord ${ }^{\text {TM }}$ biofilters (6 m) & 690 & 71 & 22 \\
$\quad$ Plastic container for filtration unit & 100 & 31 & 9 \\
$\quad$ Water pumps (2) & 1,150 & 35 & 11 \\
$\quad$ Air pump (1) & 1,100 & 34 & 10 \\
$\quad$ Japanese mat filters $\left(0.75 \mathrm{~m}^{2}\right)$ & 150 & 5 & 1 \\
Total cost of construction & 7,590 & 315 & 95 \\
Operational Cost ${ }^{2}$ & & & 1 \\
$\quad$ Tilapia & 100 & 3 & 3 \\
$\quad$ Feeds & 259 & 8 & 1 \\
$\quad$ Electricity & 75 & 2 & 100 \\
Total cost of operation & 434 & 13 & \\
Total Cost & 8,024 & 328 & \\
Revenue & & & \\
$\quad$ Tilapia (45 Baht/kg) & 468 & 14 & \\
\hline
\end{tabular}

11 US dollars $=32.5$ Baht (6 June 2014)

${ }^{2}$ Excluding labor cost under the assumption of self-employment

\section{Conclusions}

The present study aimed to assess the performance of the land-based compact aquaculture system, which integrated fibrous nitrifying biofilters and suspended solids removal. Management of suspended solids appeared as the critical aspect for successful aquaculture cultivation. Without conducting solid removal, the rapid increase of suspended solids was observed along with significant increase of TAN and nitrite concentrations above the acceptable limit of $1.0 \mathrm{mg} \mathrm{N} / \mathrm{L}$ even at low fish weights (i.e., $<5 \mathrm{~kg} / \mathrm{m}^{3}$ ). Based on the data from the present study, solid-liquid separation by filtration unit with Japanese mats as filtered media was more effective than using a single solid-separating unit. Operation of the compact aquaculture system given the total biofilter length of $6.0 \mathrm{~m}$ along with employing filtration unit and biofilter cleaning in every 4 days could maintain TAN, nitrite and suspended solid concentrations within practical ranges for extended period, thereby leading to good water quality, high fish growth rate (i.e., $3.45 \mathrm{~g} /$ day) and relatively high harvesting weight of tilapia (i.e., $10.4 \mathrm{~kg} / \mathrm{m}^{3}$ ). Based on the nitrogen mass balance calculation, significant portion of unaccounted nitrogen $(42.67 \%)$ might imply that simultaneous nitrification and denitrification were the primary means for inorganic nitrogen treatment while the presence of filtration unit was essential for prolonging the nitrifying activity of biofilters. Finally, with appropriate system adjustment, the compact aquaculture system would become more attractive for low-budget farmers and help promoting the concept of sustainable aquacultures.

\section{Acknowledgement}

This research has been supported by the Ratchadaphiseksomphot Endowment Fund of Chulalongkorn University (RES560530659-FW and RES560530189-EN).

\section{References}

[1] R. Crab, Y. Avnimelech, T. Defoirdt, P. Bossier, and W. Verstraete, "Nitrogen removal techniques in aquaculture for sustainable production," Aquaculture, vol. 270, pp. 1-14, 2007. 
[2] M. Davis, "Water quality management," in Introduction to Environmental Engineering, 2nd ed. New York, New York, USA: McGraw-Hill, Inc, 1991, ch. 4, pp. 261-309.

[3] J. Davidson, N. Helwig, and S. T. Summerfelt, "Fluidized sand biofilters used to remove ammonia, biochemical oxygen demand, total coliform bacteria, and suspended solids from an intensive aquaculture effluent," Aquacultural Engineering, vol. 39, no. 1, pp. 6-15, 2008.

[4] A. Kamstra, J. W. van der Heul, and M. Nijhof, "Performance and optimization of trickling filters on eel farms," Aquacultural Engineering, vol. 17, pp. 175-192, 1998.

[5] B. L. Brazil, "Performance and operation of rotating biological contactor in a tilapia recirculating aquaculture system," Aquaculture Engineering, vol. 34, pp. 261-274, 2006.

[6] M. B. Timmons, J. L. Holder, and J. M. Ebeling, "Application of microbead biological filters," Aquaculture Engineering, vol. 34, pp. 332-343, 2006.

[7] T. J. Pfeiffer and P. S. Wills, "Evaluation of three types of structured floating plastic media in moving bed biofilters for total ammonia nitrogen removal in a low salinity hatchery recirculating aquaculture system," Aquacultural Engineering, vol. 45, no. 2, pp. 51-59, 2011.

[8] K. Nootong, S. Nurit, and S. Powtongsook, "Control of inorganic nitrogen and suspended solids concentrations in a land-based recirculating aquaculture system," Engineering Joumal, vol. 17, no. 1, pp. 49-59, 2013.

[9] Y. Avnimelech, "Bio-filters: the need for an new comprehensive approach," Aquacultural Engineering, vol. 34, pp. 172-178, 2006.

[10] T. Sesuk, S. Powtongsook, and K. Nootong, "Inorganic nitrogen control in a novel zero-water exchanged aquaculture system integrated with airlift-submerged fibrous nitrifying biofilters," Bioresource Technology, vol. 100, pp. 2088-2094, 2009.

[11] K. Nootong, P. Pavasant, and S. Powtongsook, "Effect of organic carbon addition in controlling inorganic nitrogen concentrations in a biofloc system," Journal of World Aquaculture Society, vol. 42, pp. 339-346, 2011.

[12] APHA (American Public Health Association, American Water Works Association, and Water Pollution Control Federation) "Standard Method for the Examination of Water and Wastewater, 20th ed. Washington, D.C., USA.

[13] M. B. Timmons, J. M. Ebeling, F. W. Wheaton, S.T. Summerfelt, and B. J. Vinci, "Water quality," in Recirculating Aquaculture System, New York, USA: Cayuga Aqua Ventures, 2002, ch. 2, pp. 19-44.

[14] R. F. Malone, J. Begeron, and C. M. Cristina, "Linear versus Monod representation of ammonia oxidation rates in oligotrophic recirculating aquaculture systems," Aquacultural Engineering, vol. 34, pp. 214-223, 2006.

[15] J. A. Hargreaves, "Photosynthetic suspended-growth systems in aquaculture," Aquacultural Engineering, vol. 34, pp. 344-363, 2006.

[16] E. V. Munch, P. Lant, and J. Keller, "Simultaneous nitrification and denitrification in bench-scale sequencing batch reactor," Water Research, vol. 30, pp. 277-284.

[17] S. Silapakul, S. Powtongsook, and P. Pavasant, "Nitrogen compounds removal in a packed bed external look airlift bioreactor," Korean Journal of Chemical Engineering, vol. 22, no. 2, pp. 393-398, 2005.

[18] Y. Rahimi, A. Torabian, N. Mehrdadi, and B. Shahmaradi, "Simultaneous nitrification-denitrification and phosphorous removal in a fixed bed sequencing batch reactor (FBSBR)," Journal of Hazardous Materials, vol. 185, pp. 852-857, 2011.

[19] B. Wang, W. Wang, H. Han, H. Hu, and H. Zhuang, "Nitrogen removal and simultaneous nitrification and denitrification in a fluidized bed step-feed process," Journal of Environmental Science, vol. 24, no. 2, pp. 303-308, 2012.

[20] M. Wutikumpoln, "Effect of biofilter on water quality in TAMTIM fish Oreochromis niloticus closed culture pond," Master of Science in Environmental Science (Inter-department), Chulalongkorn University, Bangkok, 2003.

[21] J. Skjolstrup, P. H. Nielsen, F. O. Frier, and E. McLean, "Performance characteristics of fluidized bed biofilters in a novel laboratory scale recirculation system for rainbow trout: nitrification rates, oxygen consumption and sludge collection," Aquacultural Engineering, vol. 18, pp. 265-276, 1998.

[22] Y. Suzuki, T. Maruyama, H. Numata, H. Sato, and M. Asakawa, "Performance of a closed recirculating with foam separation, nitrification and denitrification units for intensive culture of eel; towards zero emission," Aquacultural Engineering, vol. 29, pp. 165-182, 2003. 
[23] H. V. Daniels and C. E. Boyd, "Chemical budgets for polyethylene-lined brackish water ponds," Journal of the World Aquaculture Society, vol. 20, pp. 53-60, 1989.

[24] M. T. Ridha and E. M. Cruz, "Effect of biofilter media on water quality and biological performance of the Nile tilapia Oreochromis niloticus L. reared in a simple recirculating system," Aquacultural Engineering, vol. 24, pp. 157-166, 2001.

[25] Y. S. Al-Hafedh, A. Alam, and M. Alam, "Performance of plastic biofilter media with different configuration in a water recirculation system for the culture of Nile tilapia (Oreochromis niloticus)," Aquacultural Engineering, vol. 29, pp. 139-154, 2003.

[26] D. C. Little, F. J. Murray, E. Azim, W. Leschen, K. Boyd, A. Watterson, and J.A. Young, "Option for producing a warm water fish in the UK: limit to "green growth"?," Trends in Food Science and Technology, vol. 19, pp. 255-264, 2008.

[27] T. Suwannarat, "Development of closed recirculating system integrating nitrifying and denitrifying biofilters for intensive aquaculture", Master of Engineering Thesis, Chulalongkorn University, Bangkok, 2010.

[28] W. Vanitchanai, "Effect of organic carbon addition on microbial floc formation and water quality in closed aquaculture system," Master of Engineering Thesis, Chulalongkorn University, Bangkok, 2009.

[29] C. Steicke, V. Jegatheesan, and C. Zeng, "Mechanical mode floating medium filters for recirculating system in aquaculture for higher solids retention and lower freshwater usage," Bioresource Technology, vol. 98, no. 17, pp. 3375-3383, 2007. 
